\title{
Nuclear localization of a new c-cbl related protein, CARP 90, during in vivo thymic apoptosis in mice
}

\author{
Ghislaine Denis $^{1,5}$, Stéphane Mandard ${ }^{2,4,5}$, Chantal Humblet ${ }^{3}$, \\ Myriam Verlaet ${ }^{1}$, Jacques Boniver ${ }^{1}$, Dominique Stéhelin ${ }^{2}$, \\ Marie-Paule Defresne ${ }^{3}$ and Daniel Régnier ${ }^{\star 2}$ \\ 1 Laboratory of Pathological Anatomy, CHU-B35, B-4000 Liège, Belgium \\ 2 CNRS-UMR 319, Institut Pasteur/Institut de Biologie de Lille, 1 rue Calmette, \\ BP 447, 59021 Lille, France \\ ${ }^{3}$ Laboratory of Histology and Cytology, L3, University of Liège, B-4020 Liège, \\ Belgium \\ ${ }^{4}$ Current address: Institut de Biologie Animale, Bâtiment de Biologie, Université \\ de Lausanne, $\mathrm{CH}-1015$ Lausanne, Switzerland \\ ${ }^{5} \mathrm{G}$. Denis and S. Mandard equally contributed to this work \\ * corresponding author: Daniel Régnier, CNRS-UMR 319, Institut Pasteur/ \\ Institut de Biologie de Lille, 1 rue Calmette, BP 447, 59021 Lille, France \\ tel: 333208710 93; fax: 3332087 11 11; e-mail: dregnier@copernic.ibl.fr
}

Received 19.10.98; revised 9.4.99; accepted 19.5.99

Edited by S. Martin

\begin{abstract}
This study investigates the involvement of the $c-c b l$ protooncogene in thymocyte apoptosis occuring in vivo after hydrocortisone treatment. In the thymus of untreated mice, a few medullary and cortical thymocytes expressed $\mathbf{p} 120^{\mathrm{cbl}}$, mainly in the cytoplasm. In the cortex, their number and distribution resemble that of apoptotic cells evidenced by TUNEL staining. The expression of $\mathrm{Cbl}$ is rapidly increased when apoptosis is triggered by hydrocortisone. This $\mathrm{Cbl}$ specific immunostaining was detected in the nucleus and is due to a Cbl-related $90 \mathrm{kDa}$ protein (CARP 90). These results show that a $\mathrm{c}-\mathrm{cbl}$ product could localize in the nucleus and suggest that it could be involved as a regulator of thymic apoptosis.
\end{abstract}

Keywords: apoptosis; c-cbl; thymus; glucocorticoid

Abbreviations: NLS: nuclear localization signal; TUNEL, terminal deoxynucleotidyl transferase-mediated dUTP-FITC nick end labeling; PBS, phosphate buffer saline

\section{Introduction}

The protooncogene $c-c b /$ has been shown to be ubiquitously expressed through Northern blot analysis of murine tissues with a preferential and spontaneous expression in the thymus and the testis. ${ }^{1}$ Two functional transcripts of 3.5 and $10.5 \mathrm{~kb}$ have been described, the larger form being predominant in the thymus.

The protein product of $\mathrm{c}-\mathrm{cbl}, \mathrm{p} 120^{\mathrm{cbl}}$ or $\mathrm{Cbl}$, has several distinctive domains including a $Y Y-1$ transcription factor-like basic region and a potential nuclear localization signal (NLS) in the N-terminal region, a RING finger motif, a large proline and serine/threonine rich domain, a leucine zipper like motif at the C-terminus ${ }^{2,3}$ and a potential phosphotyrosine binding (PTB) domain. ${ }^{4}$ Most of these features suggest that $\mathrm{C}-\mathrm{Cbl}$ could function as a transcription factor. However, different studies have shown that $\mathrm{Cbl}$ does not localize in the nucleus, unlike the product of $\mathrm{v}-\mathrm{cb}$ / which is a fusion of the first 357 amino-acid residues of $\mathrm{p} 120^{\mathrm{cbl}}$, retaining the NLS, to the viral gag sequences. ${ }^{5}$

Numerous recent studies rather lead to the assumption of a central role for $\mathrm{Cbl}$ in signal transduction. Indeed, $\mathrm{p} 120^{\mathrm{cbl}}$ is rapidly phosphorylated on tyrosine upon activation of cells through a number of receptor tyrosine kinases as well as non-receptor tyrosine kinases. Tyrosine phosphorylation of $\mathrm{Cbl}$ was observed after integrin signaling activation in macrophages. ${ }^{6} \mathrm{Cbl}$ is also phosphorylated in cells transformed by v-Src, v-Abl and Bcr-Abl. ${ }^{2,7,8} \mathrm{Cbl}$ is associated with tyrosine kinases either constitutively (srcfamily kinases) or inducibly (EGFR, PDGFR $\alpha$, Syk/ZAP-70 family in lymphocytes). It also interacts with a number of signaling molecules such as Crk/CrkL, Vav, PI3K, Grb-2 and 14-3-3 proteins (for review: ${ }^{4,9,10-15}$ ).

Much of our knowledge about c-cbl is based on studies made on cell lines in vitro, and despite its high specific physiologic expression in the thymus, the role of $c-c b l$ in thymocytes is not well understood yet.

The establishment of the T-cell repertoire in the thymus is achieved following different steps including positive and negative selection (for review: ${ }^{16}$ ) During selection, most unresponsive or potentially autoreactive thymocytes are eliminated by apoptosis. ${ }^{17}$ Thus, T-cell development requires proliferation, differentiation and apoptosis. In vitro stimulation of human thymocytes with anti-CD3 antibodies plus a comitogenic factor such as IL-1 or PMA downregulated the high level of $c-c b /$ expression observed in the presence of anti-CD3 alone. ${ }^{18}$ These results suggest that thymocyte proliferation requires a down-regulation of $c-c b /$ mRNA. They are consistent with the negative regulation which $\mathrm{Cbl}$ is believed to exert on diverse tyrosine kinases (Syk/ZAP-70 family, ${ }^{19}$ EGF and PDGF $\alpha$ receptors ${ }^{20}$ ). Our data also showed that the c-cbl mRNA level notably and rapidly increased through CD3 stimulation which leads to thymocyte apoptosis. ${ }^{18}$ As apoptosis is required for T-cell development, this prompted us to investigate the in vivo expression of $\mathrm{Cbl}$ after induction of thymocyte apoptosis by glucocorticoids.

The present paper describes the expression of c-cbl mRNA and the presence as well as the subcellular localization of the protein product(s) in the normal mouse thymus and after apoptosis induction in vivo. Our results confirm the expression of $c-c b l$ transcripts and show their appearance around birth. They demonstrate the cytoplas- 
mic presence of $\mathrm{p} 120^{\mathrm{cbl}}$ in thymocytes of untreated mice, mainly in the cortex. During experimentally induced apoptosis, we show a very rapid increase and a nuclear localization of a $90 \mathrm{kDa} \mathrm{c}-\mathrm{cbl}$ protein product, preceeding the cleavage of the nuclear chromatin, characteristic of apoptosis.

\section{Results}

\section{c-cbl transcripts are expressed in the neonatal and in the adult thymus}

The pattern of expression of the proto-oncogene $c-c b /$ was studied by in situ hybridization using $\left({ }^{35} \mathrm{~S}\right) \mathrm{RNA} \mathrm{c}-\mathrm{cb}$ specific 10.7 kb probe.

$\mathrm{c}-\mathrm{cbl}$ expression was studied in fetal thymuses from embryonic stages E14 to E20 and during the neonatal period. The distribution and density of silver grains indicate that $c-c b l$ starts to be expressed around birth in the cortex (Figure $1 \mathrm{~A}$ ) and at the cortico-medullary junction.
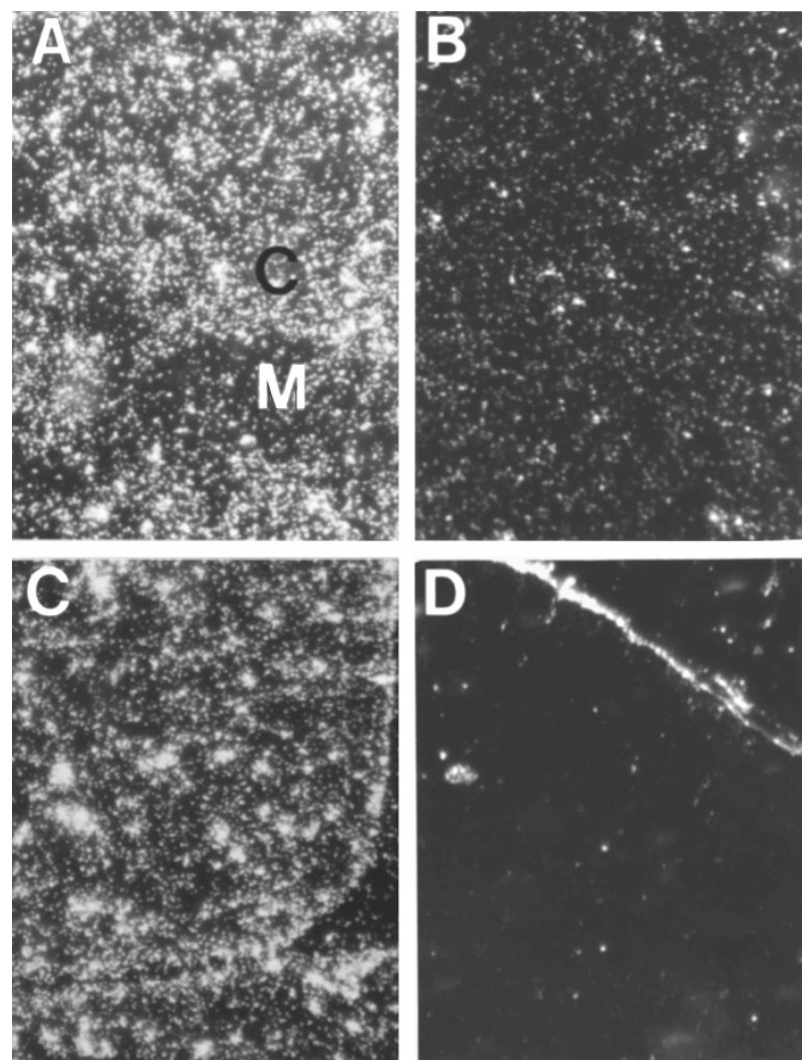

Figure 1 Expression of $\mathrm{c}-\mathrm{cb} /$ transcripts in the thymus as detected by in situ hybridization with $\mathrm{a}^{35} \mathrm{~S}$-labeled probe. Sections are observed under dark-field illumination: positive cells appear in white. Cortical and medullary areas are indicated respectively as $\mathbf{C}$ and $\mathrm{M}$. (A) In situ hybridization of the neonatal thymus shows staining in the cortex and in the medulla with a higher density of silver grains in the cortex. (B) The adult thymus presents positivity in the cortex. (C) One hour after hydrocortisone treatment, large clusters of cells are positive for the $\mathrm{c}-\mathrm{cb} /$ probe in the thymus cortex. (D) As controls, thymic sections are treated with a ${ }^{35}$ S labeled sense probe. Magnifications: A, B, C, D: $\times 2800$
In the thymus of young adult C57BL mice (Figure 1B), ccbl expression was observed mainly in the cortex: the density of silver grains in the cortical region was higher than that detected in the medulla (not presented on the picture); these grains are uniformly dispersed in these regions. As compared with control sense probe hybridizations (Figure 1D), these levels of expression can be considered as significant.

Thus, $c-c b l$ transcripts were not present in the fetal thymus and started to be detected around birth. They persisted mainly in the thymus cortex during adult life.

\section{The $120^{\mathrm{cbl}}$ protein is expressed in the thymus}

To investigate the $c-c b l$ expression at the protein level, immunohistochemistry was performed on thymus sections from untreated 1-month-old adult mice (Figure 2A), using a rabbit polyclonal antibody directed against the last 15 amino acids at the carboxy terminus of $\mathrm{p} 120^{\mathrm{cbl}}$. This experiment revealed that $c-c b l$ product(s) are present mainly in the cytoplasm of isolated lymphoid cells scattered in the cortex, but also in medullary thymocytes and some stromal cells.

Western blots analysis of total thymic extracts, with the same antibody, showed a signal clearly detectable at $120 \mathrm{kDa}$, confirming that $\mathrm{p} 120^{\mathrm{cbl}}$ is indeed present in the thymus of untreated adult mice.

\section{The cleavage of nuclear chromatin characteristic of apoptosis is detected in the neonatal and in the adult thymus}

Experiments described above revealed the presence of $c-c b l$ transcripts and protein products mainly in areas of the thymus where apoptosis is thought to occur. We thus examined a biochemical marker for apoptosis, the cleavage of nuclear chromatin. Terminal deoxynucleotidyl transferase (TdT)mediated dUTP-FITC nick end-labeling (TUNEL) detects DNA strand breaks in cells undergoing apoptosis. Thus, unlike normal cells, nuclei of apoptotic cells incorporate exogenous nucleotides (dUTP-FITC) in the presence of TdT. When amplified with a two step staining procedure, the TUNEL method readily detects apoptotic cells in cryostat sections.

In the adult thymus (Figure 3Aa), some isolated TUNEL stained cells were mainly found in the cortex; very few positive cells were detected in the medulla. TUNEL positivity in the fetal thymus was quite low or absent starting to be detected by day 2 after birth, mostly in the cortex and at the cortico-medullary junction where their density was higher than in the adult thymus.

\section{Hydrocortisone very rapidly increased c-cbl products $(\mathrm{Cbl})$ expression and induced a nuclear localization of these products before the onset of apoptosis}

The scarceness of apoptotic thymocytes observable in a thymus section, probably due to the rapid elimination of dead 

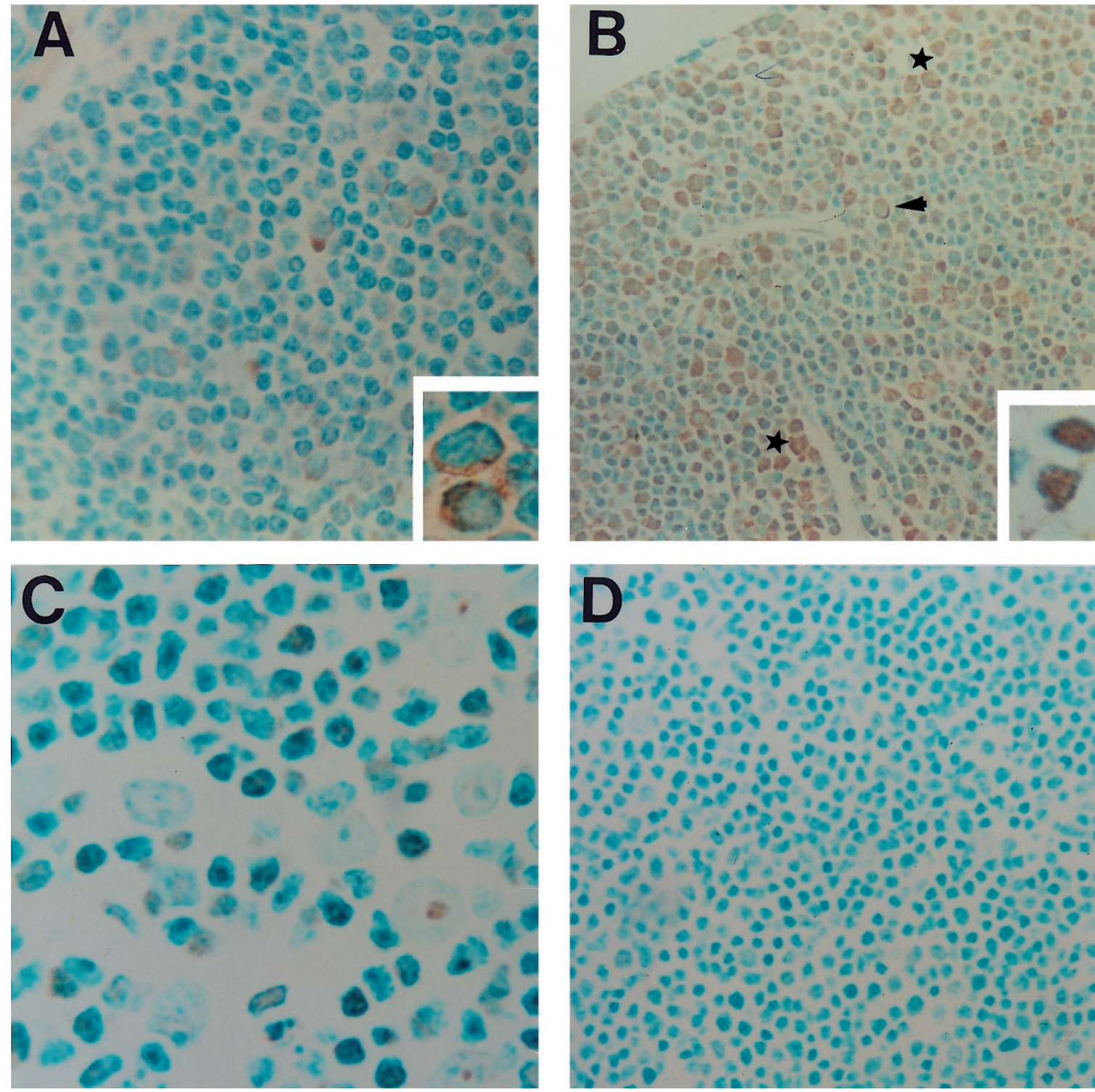

Figure $2 \mathrm{Cbl}$ immunoreactivity in the thymus. (A) Thymic cortex of 1-month-old mouse shows very few stained cells (in brown), with immunoreactivity localized in the cytoplasm (insert). (B) Thymic cortex of 1-month-old mice, $15 \mathrm{~min}$ after hydrocortisone treatment shows a drastic increase in the density of positive cells, with immunoreactivity either in the nucleus (insert), or in the cytoplasm (arrowhead) or both in the cytoplasm and in the nucleus (stars). (C) Thymic cortex of 1-month-old mouse, $12 \mathrm{~h}$ after hydrocortisone treatment, shows almost no $\mathrm{Cbl}$ immunostaining. (D) Control: thymic cortex of 1-month-old mouse, 15 min after hydrocortisone treatment, incubated simultaneously with anti-cbl antibodies and P15 immunogen peptide, shows no staining. Magnifications: A, B, D: $\times 1400$, C: $\times 2200$, inserts: $\times 5500$

cells in vivo, makes the correlation between Cbl expression and apoptosis difficult to establish. To bypass this limitation and to check whether $\mathrm{Cbl}$ expression was modified when thymocytes undergo apoptosis, we used hydrocortisone for the in vivo induction of massive apoptosis inside the thymus. ${ }^{21}$

Hydrocortisone induced a rapid and marked increase in the number of apoptotic cells, mainly in the cortex, but also in the medulla; the apoptotic cells were detected as soon as $2 \mathrm{~h}$ after the injection and aggregated in large clusters, mainly in deep cortex and at the cortico-medullary junction (Figure 3Ab).
Agarose gel electrophoresis of DNA confirmed the occurrence of apoptosis in thymuses of hydrocortisonetreated mice (Figure 3B).

Then, we examined the pattern and the time course of $\mathrm{Cbl}$ expression in the thymus after apoptosis induction by hydrocortisone injection. We observed a very early increase in the number of cells stained with anti-Cbl antibodies: as soon as 15 min after hydrocortisone treatment (Figure 2B), many positive cells which still display a healty morphology were detected. During the earlier part of the time course experiment, as apoptosis was occuring (15 $\mathrm{min}$ to $6-8 \mathrm{~h}$ after the treatment), the labeling intensity increased, as well 

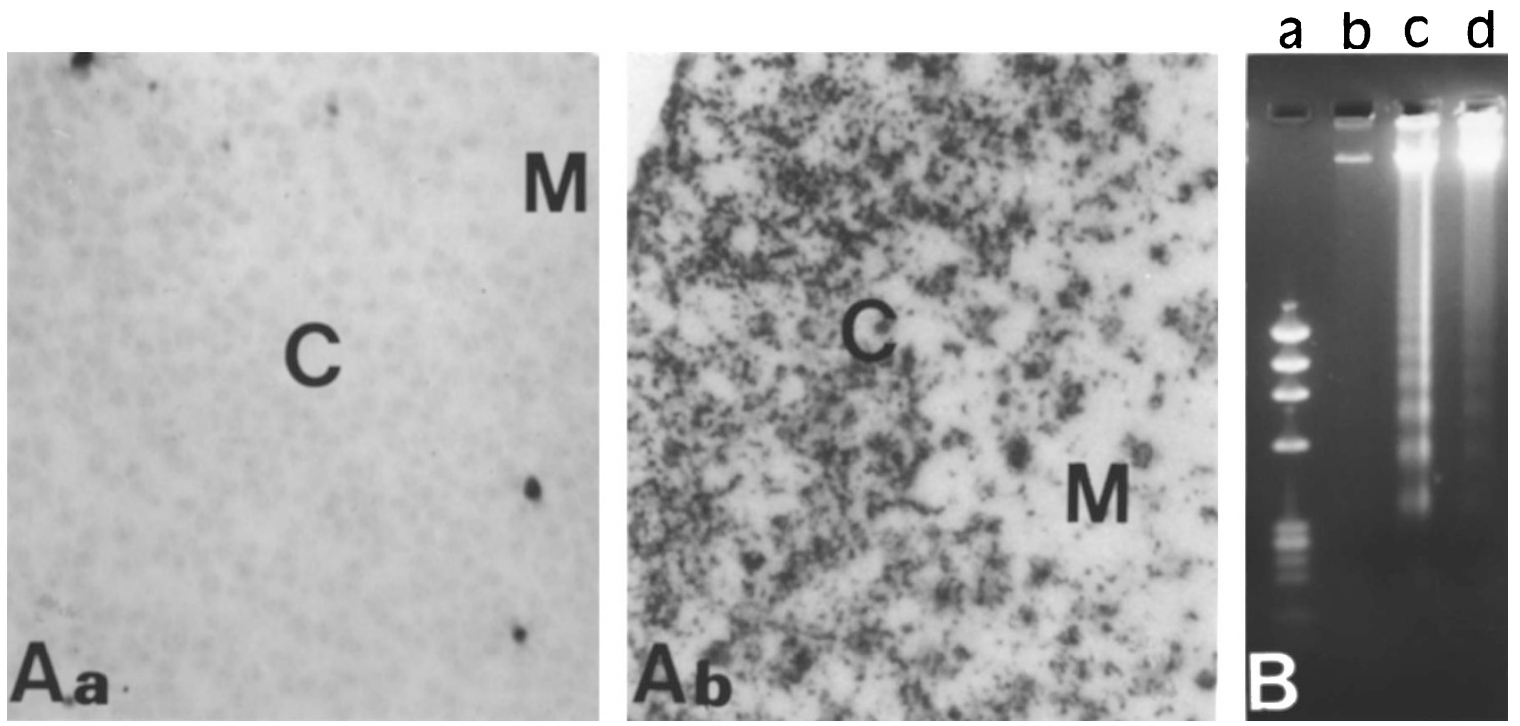

Figure 3 Hydrocortisone induced apoptosis in the thymus. (A). TUNEL assay was performed on thymus sections from 1-month-old control mice (a) and $2 \mathrm{~h}$ after hydrocortisone treatment (b). Cortical and medullary areas are indicated respectively as C and M, apoptotic cells appear in black. (B) Internucleosomal DNA fragmentation was assessed by DNA electrophoresis. Lane a: Molecular Weight control, lane b: normal thymus, lanes $\mathrm{c}$ and $\mathrm{d}$ : thymus from mice $2 \mathrm{~h}$ after hydrocortisone treatment

as the number of positive cells. In most of these cells, an anti-Cbl immunoreactive product was present in the nucleus, while some cells seemed to express Cbl only in their cytoplasm. No staining was observed when sections were incubated with antibody pre-incubated with the immunogen peptide in an appropriate ratio (P15) (Figure 2D). Then, when apoptosis had already occured (16-48 h after the treatment), we observed almost no more $\mathrm{Cbl}$ immunostaining (Figure 2C).

\section{Nuclear immunoreactivity with anti-Cbl antibodies is due to the presence of a $\mathbf{9 0} \mathbf{k D a}$ protein}

The observations made by light microscopy after immunostaining seem to indicate that $\mathrm{Cbl}$ expression is increased and present in the nucleus when thymic apoptosis is triggered. To confirm this nuclear localization, $c-c b /$ products were further analyzed on cytoplasmic and nuclear thymocyte extracts by immunoprecipitations with anti $\mathrm{p} 120^{\mathrm{cbl}}$, followed by Western blotting with the same antibody.

In normal thymocytes, two immunoreactive forms were observed: $p 120^{\mathrm{cbl}}$ in the cytoplasm (Figure 4A, lane 7) and a protein of $90 \mathrm{kDa}$ in the nucleus (Figure $4 \mathrm{~A}$, lane 1 ). Fifteen minutes after hydrocortisone treatment, $\mathrm{p} 120^{\mathrm{cbl}}$ was still detected only in the cytoplasm (Figure 4A, lane 5 compared to lane 7). At this time, the $\mathrm{Cbl}$ immunoreactive p90 signal appeared strongly in the cytoplasm (Figure 4A, lane 5) and increased to a slight extent in the nucleus (Figure 4A, lane 3 compared to lane 1). Immunoprecipitations done with the anti-Cbl antibody pre-incubated with the immunogen peptide $(\mathrm{P} 15)$ in an appropriate ratio do not reveal $\mathrm{p} 120^{\mathrm{cbl}}$ (Figure 4A, lanes 8 and 6) nor the $90 \mathrm{kDa}$ protein (Figure 4A, lanes 6 and 2). Moreover, incubation of the anti-Cbl antibody with a lesser amount of blocking peptide notably reduced the p90 signal (Figure 4A, lane 4 compared to lane 3) without completely switching it off. These results support the specificity of the signals. In this experiment, immunoprecipitations were done on the same amount of protein from cytoplasmic or nuclear extracts.

Another time course experiment showed a drastic appearance of p90 in the cytoplasm as soon as $5 \mathrm{~min}$ after hydrocortisone treatment (data not shown), and a progressive increase in the nucleus between 15 and 30 min (Figure 4B). These data confirm the nuclear localization as well as the increasing nuclear expression of p90 already 15 min after treatment (Figure 4A, lane 3), reaching a peak $1 \mathrm{~h}$ after treatment (Figure 4B). This could be ascribed to a progressive recruitment of cells undergoing such a phenomenon and/or to an accumulation of the nuclear c$\mathrm{cbl}$ related product in these cells. We concluded that the nuclear as well as part of the cytoplasmic staining with the anti-Cbl antibody on thymic sections is due to the presence of this $\mathrm{Cbl}$ immunoreactive $90 \mathrm{kDa}$ protein. Its weak constitutive presence within the nucleus of normal control thymocytes (Figure 4A, lane 1) could be due to the physiological and basal apoptosis occurring in the thymus.

\section{An increase of $c-c b l$ mRNA level following hydrocortisone treatment occurs later on after the accumulation of $\mathbf{c - c b l}$ protein products}

To further investigate how $\mathrm{Cbl}$ could be up-regulated by apoptosis inducers, the pattern and time course of c-cbl mRNA expression was analyzed by in situ hybridization on thymus sections after apoptosis induction as described above.

Fifteen and 30 min after apoptosis inducing treatment, the hybridization signal was equivalent to that found in 


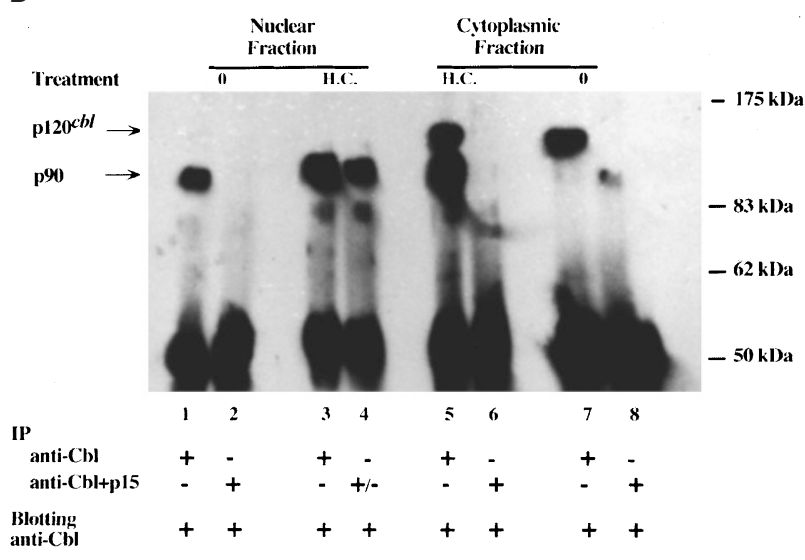

B

\section{Nuclear extracts}

Time (min)

after H.C. treatment.

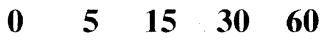

90 p90

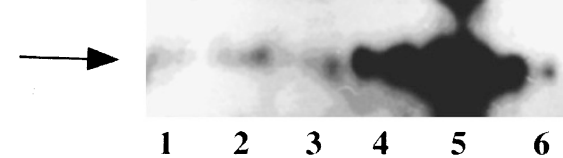

Figure 4 Appearance of a new cytoplasmic and nuclear $\mathrm{Cbl}$ immunoreactive form of $90 \mathrm{kDa}$ in the thymus of hydrocortisone treated mice. (A) Immunoprecipitation and immunoblotting with the same anti-Cbl antibody (C-15, Santa Cruz) on cytoplasmic and nuclear thymic extracts from mice 15 min after hydrocortisone treatment (lanes 3, 4, 5 and 6) as compared to fractionated thymic extracts from untreated animals (lanes 1,2, 7 and 8). There is no immunoprecipitation when anti-Cbl antibody was blocked with the P15 blocking immunogen peptide in a sufficient ratio (lanes 2, 6 and 8). Incubation of the antibody with diluted P15 led to a decrease in the p90 signal in the nucleus (lane 4 compared to lane 3 ) confirming the $\mathrm{Cbl}$ specificity of the antibody recognition. Tracks were equimolarly loaded. (B) Immunoprecipitation and immunoblotting with the same anti-Cbl antibody on thymic nuclear extracts from untreated (lane 1) or treated animals. As compared to the previous experiment, immunoprecipitation was done on a five to ten lesser amount of nuclear proteins and nevertheless led to a very high p90 signal $30 \mathrm{~min}$ and more after hydrocortisone treatment (lanes 4 and 5)

thymuses of untreated mice. High levels of $c-c b /$ transcripts were found only 1 to $2 \mathrm{~h}$ thereafter, when many apoptotic cells had already been observed, mainly in cell clusters in the cortex of hydrocortisone-treated mice (Figure 1C).

These data suggest that a neosynthesis of the p90 does not account for the very early accumulation of this protein following apoptogenic treatment.

\section{Discussion}

The $c-c b l$ product, $p 120^{\mathrm{cbl}}$, contains several features distinctive of transcription factors, particularly a putative nuclear localization signal (NLS), a YY-1 transcription factorlike basic region, a putative leucine zipper and a zinc fingerrelated protein motif. The truncated protein encoded by $\mathrm{v}-c b$ l can enter the nucleus and bind to DNA. ${ }^{22}$ However, p120 $12 \mathrm{cbl}$ has never been shown to localize in the nucleus but rather seem to be involved in signal transduction within the cytoplasm of various cell lines. The main $c-c b /$ constitutive expression within the thymus and its apparent lack of involvement in cell-cycle processes ${ }^{18,23}$ prompted us to explore $\mathrm{Cbl}$ fate through another major event occurring in the thymus, apoptosis.

Potent apoptosis inducer such as hydrocortisone led to a rapid increase of $\mathrm{Cbl}$ expression, markedly in the nucleus, as shown by immunohistochemistry experiments, both in the cortex and the medulla. This increase preceded the DNA fragmentation characteristic of apoptosis. These data led us to the assumption that $c-c b l$ could play a role in thymic apoptosis regulation, but also suggested that this function could depend on the cell type, the developmental stage and the microenvironment influence, as it is the case for c-rel. ${ }^{24}$ Immunoprecipitation followed by immunoblotting with anti-Cbl antibody (C-15) showed that a c-Cbl immunoreactive protein of $90 \mathrm{kDa}$ is mainly involved in the nuclear immunostaining whereas $\mathrm{p} 120^{\mathrm{cbl}}$ stays in the cytoplasm.

Similar in situ immunostaining was observed after treatment with other potent thymocyte apoptosis inducers such as 4 Gy irradiation or anti-CD3 monoclonal antibody. A p90 nuclear Cbl-immunoreactive form was also detected after the same treatments (data not shown). These results indicate that $\mathrm{c}-\mathrm{cb}$ / may have a nuclear p90 form tightly associated to the occurence of thymic apoptosis and suggest a critical role for $\mathrm{p} 90$ in apoptosis regulation. We named this protein CARP 90 for $\mathrm{Cbl}$ and Apoptosis Related Protein $90 \mathrm{kDa}$.

The rapid appearance of this p90 in the cytoplasm before it could be detected at a high level in the nucleus strikingly suggests a nuclear transport event, even if a nuclear accessibility to anti-Cbl antibody upon apoptosis inducer treatments cannot be ruled out.

This $p 90$ is likely related to the $c-c b /$ proto-oncogene according to the following observations: (a) there is no protein known in the data bank which shares significative homologous sequence within the peptide sequence recognized by the anti-Cbl antibody used in these experiments (C-15); (b) the cbl immunoreactive signal at $90 \mathrm{kDa}$ following thymic $\mathrm{Cbl}$ immunoprecipitation after apoptosis induction is reproducibly higher than the $\mathrm{p} 120^{\mathrm{cbl}}$ signal (Figure 4A, lane 5). This C-Cbl immunoreactive p90 could be a product of a closely related gene. In this respect, the proto-oncogene $c b /-b$, which shares a high homology with $c-c b^{25}$ is not a good candidate, since the polyclonal antibody used in these experiments (C-15) is described as not cross-reacting with $\mathrm{cbl} / \mathrm{b}$ products. The $\mathrm{Cbl}$ related p90 was also precipitated and reactive in immunoblotting with a polyclonal anti-Cbl-b antibody crossreacting with large parts of $\mathrm{p} 120^{\mathrm{cbl}}(29-483$ amino acids region). Conversely, two other anti-Cbl-b antibodies, which do not cross-react with $\mathrm{p} 120^{\mathrm{cbl}}$, were unable to precipitate nor detect p90 (data not shown). However, as these two antibodies are directed against the 19 first amino acids at the $\mathrm{N}$-terminus and against the last 20 amino acids at the C-terminus of Cbl-b, it is thus possible to hypothesize that these sequences have been lost, resulting in a truncated form. At last, a monoclonal antibody (Transgene Labora- 
tories, clone 17), directed against a $\mathrm{p} 120^{\mathrm{cbl}}$ region comprised between amino acids 595 and 810, could detect p90 (and p120) (data not shown). So, p120 ${ }^{\mathrm{cbl}}$, having been suspected for a long time to be a transcription factor according to its sequence, could reasonably be linked to this strongly $\mathrm{c}-\mathrm{Cbl}$ immunoreactive nuclear protein of $90 \mathrm{kDa}$ (CARP 90) shown for the first time in the thymus. The originality of our work lies in that we have investigated the $\mathrm{Cbl}$ expression in an apoptosis model by immunohistochemistry and immunoprecipitations on fractionated extracts, as nobody had done yet. That could partially but reasonably explain why almost nobody had ever been able to observe nuclear products of $\mathrm{c}-\mathrm{cbl}$, before our own data.

In order to correlate $\mathrm{p} 90$ with $c-c b l$ mRNA, the pattern and time course of $c-c b l$ mRNA expression were investigated by in situ hybridization on thymus sections after in vivo apoptosis induction by hydrocortisone injection. The hybridization signal was not significantly different within 30 min following the treatment as compared to untreated animals (data not shown). After $1-2 \mathrm{~h}$, when a high number of apoptotic cells was already being observed, we noticed a striking change with many $c-c b l$ transcripts mainly found in numerous large clusters of cortical cells (Figure 1C). The strongest modifications were observed $2 \mathrm{~h}$ after treatment while $\mathrm{Cbl}$ immunoreactive protein(s) were detected very early (15-30 $\mathrm{min}$ ) after the same treatment, by immunohistochemistry on thymic sections (Figure $2 \mathrm{~B}$ ) or by immunoprecipitation (Figure $4 \mathrm{~A}$ ) with anti-Cbl antibody. These data suggest that a neosynthesis of CARP 90 does not account at least for the very rapid increase of the protein levels following apoptogenic treatment.

As evoked above, the rapid appearance of a $\mathrm{Cbl}$ immunoreactive protein of $90 \mathrm{kDa}$ in the cytoplasmic extract after treatment (Figure 4A) could be due to the unmasking of epitopes recognized by the anti-Cbl antibody following the treatment. The nuclear presence of $p 90$ could be associated with an unmasking of the putative NLS through either an intra-molecular event (as it is the case for NF-AT $4^{26}$ ), a proteolytic maturation cleavage of $\mathrm{p} 120^{\mathrm{cbl}}$ or the release of one or more potential binding proteins. Closely related to this situation is the rapid degradation of $\mathrm{IkB} \alpha$ when cells are exposed to NF- $\kappa \mathrm{B}$ inducers, allowing the transcriptional complex to translocate into the nucleus. ${ }^{27}$ Apoptosis inducers could have the same effect on a complex containing p90. Moreover, these results are reminiscent of the transcription factor c-rel, which has been shown to translocate into the nucleus of avian thymocytes during the time course of apoptosis through a posttranscriptional induction. ${ }^{28}$

As for the hypothesis that the $\mathrm{Cbl}$ immunoreactive p90 could result from a proteolytic post-translational event, we could refer to Widmann et al. ${ }^{29}$ who have shown that $\mathrm{Cbl}$ was cleaved in Jurkat and U937 cells undergoing apoptosis induced by different stimuli. This cleavage occured rather late in the apoptotic process and thus seemed to be a consequence rather than an initiating event of apoptosis in their system, contrasting with the early appearance of CARP 90 after apoptosis induction in our experiments. In their study, it appeared that Cbl cleavage was caspase- activation dependent, but DEVD-directed caspases, e.g. caspase-3 family, were not involved. Furthermore, Miyashita et al. ${ }^{30}$ showed that the glucocorticoid-induced apoptotic pathway would involve the processing of caspase- 6 rather than caspase- 3 activation. Furthermore, CPP32 (caspase-3) would not play any key role in $\mathrm{T}$ cell selection. ${ }^{31}$ On the other hand, caspases are not the only proteases involved in apoptosis. In this respect, it is noteworthy that Widmann et al. ${ }^{29}$ still detected a Cblrelated product after Fas ligation and caspases inhibition in Jurkat cells. The pattern of $\mathrm{p} 120^{\mathrm{cbl}} \mathrm{cDNA}$ in vitro transcribed and translated proteins in our own system was similar to that obtained by Widmann et al. ${ }^{29}$ (data not shown), i.e. a $85 \mathrm{kDa}$ Cbl-related product was detected by the $\mathrm{C}-15$ anti-Cbl antibody. This $85 \mathrm{kDa}$ product could result from an internal initiation of translation or from a proteolytic event due to proteases inside the reticulocyte lysate system. Thus, it is possible that the Cbl-related product at $85 \mathrm{kDa}$ obtained in vitro corresponds to the p90 found in vivo. Experiments are currently performed to analyze the pattern when in vitro products are incubated with apoptosis-induced thymocytes.

As the sequence recognized by the polyclonal antibody used in our experiments is located at the C-terminus part of p120 $\mathrm{cbl}$, we could imagine $\mathrm{p} 90$ as a proteolytically processed form of $\mathrm{c}$-Cbl lacking some $\mathrm{N}$-terminal sequence. However, even if the existence of a cryptic NLS cannot be ruled out, the transcription factor-like basic region and the putative NLS are located in the aminoterminal part of c-Cbl. Alternatively, p90 could be the product of an alternative spliced $c-c b l$ mRNA. This hypothesis is currently being examined by RT-PCR approach.

If p90 is related to $\mathrm{c}-c b$, it will be of great interest to investigate and compare its function(s) with those of $\mathrm{p} 120^{\mathrm{cbl}}$. The large diversity of protein family members with different functions is well documented. For example, each STAT family member contributes to specific biological activities but all are transcription factors. ${ }^{32}$ A precedent for $c-c b l$ could be the lkaros isoforms with distinct subcellular compartmentalization suggesting their participation in distinct regulatory pathways either in the cytoplasm or in the nucleus. ${ }^{33}$

It is noteworthy that $\mathrm{p} 120^{\mathrm{cbl}}$ can bind with diverse proteins involved in apoptosis under certain circumstances, e.g. with p85 $\mathrm{PI}^{3} \mathrm{~K}^{34,35}$, p59 fyn ${ }^{36}, \mathrm{c}-\mathrm{Abl}^{37}$ or $14-3-3$ proteins. ${ }^{38}$ Thus, it would be interesting to investigate potential associations of p90 with other proteins, including $\mathrm{p} 120^{\mathrm{cbl}}$.

Furthermore, $\mathrm{p} 120^{\mathrm{cbl}}$ has been involved in inhibitory and/ or proteolytic regulation related processes. ${ }^{19,39-41}$ Indeed, recent biochemical studies in mammalian cells, $C$. elegans and Drosophila have identified the proto-oncogene product $\mathrm{Cbl}$ as a possible negative regulator of tyrosine kinases (for review: ${ }^{4 ; 42,43}$ ). Particularly, Crk proteins could link $\mathrm{Cbl}$ to a small G-protein signaling pathway that may antagonize Ras signaling. It has also been claimed that $\mathrm{Cbl}$ enhances the ubiquitination and degradation of the PDGFR $\alpha{ }^{44}$ and the EGFR. ${ }^{45}$ Interestingly, $c-c b l$ is localized within the same gene cluster as the gene coding for the transcription factor Ets- $1^{46}$ which would delay thymic apoptosis. ${ }^{47}$ 
Cbl knock-out mice have recently been generated independently by two groups. According to Murphy et al. ${ }^{19} \mathrm{cbl}^{-1-}$ mice display hyperplastic histological changes and enhanced T-cell signaling via ZAP-70, but correct ratio between thymic CD4/CD8 subpopulations and a thymic cellularity that is only transiently increased. Naramura et al. ${ }^{48}$ obtained similar results and showed an enhanced thymic positive selection in Cbl-deficient mice. Although the role of $\mathrm{Cbl}$ in controlling cellular proliferation as a negative regulator of tyrosine kinases is becoming more and more evident, a potential role of $\mathrm{Cbl}$ in apoptosis regulation would be worthy of investigation in these Cbl-deficient mice.

Our data as well as the c-cbl ORF sequence analysis ${ }^{2,3}$ suggest that the $c-c b /$ product(s) and particularly CARP 90 could exert a regulation, either positively or negatively, on apoptosis as transcription factor(s) at least in immature $\mathrm{T}$ cells.

\section{Material and Methods}

\section{In situ hybridizations}

In situ hybridizations were done as described ${ }^{49}$ with ${ }^{35}$ S-labeled RNA probes prepared from a $500 \mathrm{bp} P s t l-E c o R I$ of a $5^{\prime} \mathrm{v}-\mathrm{cbl} / \mathrm{c}-\mathrm{cbl}$ identity region. ${ }^{23}$ Fifty microliters of probe mixture of $50 \%$ formamide containing $\mathrm{NaCl}(0.6 \mathrm{M})$, Tris- $\mathrm{HCl}(10 \mathrm{mM})$, EDTA $(1 \mathrm{mM}), 1 \% \mathrm{SDS}$, DTT $(10 \mathrm{mM})$, yeast t-RNA $(0.25 \mathrm{mg} / \mathrm{ml}$; Boehringer Mannheim), $1 \times$ Denhardt's $(50 \times$ Denhardt's $=1 \%$ Ficoll, $1 \%$ polyvinylpyrrolidine, $1 \%$ BSA), $10 \%$ PEG-6000 (polyethylene glycol-6000) and $1 \mathrm{ml}$ of labeled RNA (150,000 c.p.m./ml) were loaded on each slide and hybridization was performed at $50^{\circ} \mathrm{C}$ overnight in a humid chamber. As negative controls, some slides were pretreated for $2 \mathrm{~h}$ at $37^{\circ} \mathrm{C}$ in a solution containing $20 \mathrm{mg} / \mathrm{ml}$ of RNAse to destroy the mRNA or, in some cases, the antisense probe was replaced by the sense probe. Slides were then washed twice for 5 min with PBSM (phosphate buffer saline containing $5 \mathrm{mM} \mathrm{MgCl}_{2}$ ), rinsed $30 \mathrm{~min}$ in a solution containing $20 \mathrm{mg} / \mathrm{ml}$ of RNAse (Boehringer Mannheim) in $0.5 \mathrm{M} \mathrm{NaCl}$ and $10 \mathrm{mM}$ Tris- $\mathrm{HCl}(\mathrm{pH} 8)$ at $37^{\circ} \mathrm{C}, 30 \mathrm{~min}$ in the same solution except RNAse at $37^{\circ} \mathrm{C}, 30 \mathrm{~min}$ with $50 \%$ formamide $/ 2 \times \mathrm{SSC}(2 \times \mathrm{SSC}=0.3 \mathrm{M} \mathrm{NaCl}$, $0.03 \mathrm{M}$ sodium citrate) at $50^{\circ} \mathrm{C}, 30 \mathrm{~min}$ with $50 \%$ formamide $/ 1 \times \mathrm{SSC}$, and $30 \mathrm{~min}$ in $50 \%$ formamide/ $1 \times$ SSC containing $0.05 \%$ of Triton X100 at $37^{\circ} \mathrm{C}$. The slides were then dehydrated successively in 30,50 and $70 \%$ ethanol in $300 \mathrm{mM}$ ammonium acetate $(\mathrm{pH} 7)$, air dried, and finally autoradiographed. Ilford K2 emulsion was diluted with an equal volume of $300 \mathrm{mM}$ ammonium acetate. The slides were dipped into the emulsion and allowed to solidify horizontally at room temperature for $4 \mathrm{~h}$. The emulsion-coated slides were kept at $4^{\circ} \mathrm{C}$ for $8-10$ days for exposure. They were developed in Kodak D-19 developer (Eastman Kodak, Rochester, NY, USA) for $3 \mathrm{~min}$. After a rinse in a $1 \%$ acetic acid solution, the fixation was carried out in an llford rapid fixer for $6 \mathrm{~min}$ and the slides were washed twice with water for $30 \mathrm{~min}$. They were stained with hematoxylin-eosin for $2 \mathrm{~min}$, washed twice with water, and air dried. We considered as positive cells (cells expressing mRNAs) those cells that had more than eight grains per cell. Dark-field photomicrographs were obtained with a Leitz Laborlux.

\section{Apoptosis detection}

TUNEL assays were performed on frozen sections according to procedures previously described (In situ cell death detection kit, AP,
Boehringer Mannheim). Sections were fixed $20 \mathrm{~min}$ in paraformaldehyde $4 \%$ at room temperature and possibly dehydrated $2 \mathrm{~min}$ in pure alcohol for conservation at $-20^{\circ} \mathrm{C}$ before further processing. Sections were permeabilized (Triton X-100 $0.1 \%$ in sodium citrate $0.1 \%$ ) $10 \mathrm{~min}$ at $37^{\circ} \mathrm{C}$, and then incubated $1 \mathrm{~h}$ at $37^{\circ} \mathrm{C}$ with $50 \mu \mathrm{l}$ of a mixture containing TdT enzyme and FITC-labeled nucleotides. Converter AP was then applied for $30 \mathrm{~min}$ at $37^{\circ} \mathrm{C}$. Alkaline phosphatase was finally revealed with New Fushine (DAKO) and sections were counterstained.

Internucleosomal DNA fragmentation was assessed by DNA electrophoresis. ${ }^{50}$ Briefly, cells were washed twice with PBS and spun at $200 \times g$ for $5 \mathrm{~min}$ at room temperature. Cell pellets were resuspended at $10^{7}$ cells $/ \mathrm{ml}$ in cell lysis bufer (10 mM EDTA, $50 \mathrm{mM}$ Tris, $0.5 \%$ SDS) and incubated for $1 \mathrm{~h}$ at room temperature. Proteinase $\mathrm{K} 10 \mu \mathrm{g} / \mathrm{ml}$ (Boehringer Mannheim) was then added and incubation was continued for $3 \mathrm{~h}$ at $37^{\circ} \mathrm{C}$. The crude DNA preparations were then extracted with phenol/chloroform. The aqueous phase was made $100 \mathrm{mM} \mathrm{NaCl}$ and precipitated overnight with 2 volumes of ethanol at $-20^{\circ} \mathrm{C}$. After centrifugation at $13000 \times g$ for $10 \mathrm{~min}$, pellets were air-dried, resuspended in $80 \mu \mathrm{l}$ of TE (10 mM Tris, $1 \mathrm{mM}$ EDTA) containing RNAse (100 $\mu \mathrm{g} / \mathrm{ml}$; Sigma) and incubated for $4 \mathrm{~h}$ at $37^{\circ} \mathrm{C}$. The crude DNA preparation was extracted as described before. Electrophoresis of DNA was carried out in $1.8 \%$ agarose gel. Prior to electrophoresis, $40 \mu \mathrm{l}$ of TE and $4 \mu \mathrm{l}$ of bromophenol blue were added to each sample. The samples were then treated to $65^{\circ} \mathrm{C}$ for $5 \mathrm{~min}$ in a water bath. The electrophoresis was carried out at $40 \mathrm{~V}$ in a TAE buffer (0.04 M Tris-Acetate, $0.001 \mathrm{M}$ EDTA, pH 9) during $4 \mathrm{~h}$. An Haell digest of $\phi 174$ RF DNA was applied to provide size markers. DNA was visualized by bromide staining and UV transillumination.

\section{Immunohistochemistry}

Immunochemistry was performed on $2 \mu \mathrm{m}$ thin histological sections done in $4 \%$ paraformaldehyde fixed and JB4 (Polysciences) embedded tissues. Sections were permeabilized with trypsine $0.25 \%$ for $10 \mathrm{~min}$ at $37^{\circ} \mathrm{C}$, and then with Tween $202 \%$ for $30 \mathrm{~min}$ at $37^{\circ} \mathrm{C}$. Endogenous peroxidases were quenched by incubation with $\mathrm{H} 2 \mathrm{O} 21 \%$ for $30 \mathrm{~min}$ at room temperature. Aspecific sites were saturated with normal goat serum $1.5 \%$ during $1 \mathrm{~h}$ at $37^{\circ} \mathrm{C}$. Sections were then incubated overnight at $4^{\circ} \mathrm{C}$ with primary polyclonal rabbit anti-cbl antibody at the concentration of $0,4 \mu \mathrm{g} / \mathrm{ml}$ (C-15, Santa Cruz Biotechnology) and then for $2.5 \mathrm{~h}$ with biotinylated goat anti-rabbit antibody. This latter was detected by ABComplex (Novostain Super $A B C$ Kit, Novocastra). Peroxidase was revealed using diaminobenzidine (DAB) (Dako) which gives a brown precipitate in the presence of $\mathrm{H}_{2} \mathrm{O}_{2}$. Sections were counterstained with methyl green $0.1 \%$ (Sigma). The specificity was successfully tested by incubating sections with normal rabbit serum instead of primary antibody, or with antibody preincubated with control peptide (SantaCruz Biotechnology).

\section{Subcellular fractionation, immunoprecipitation and Western blottings}

All manipulations were done at $4^{\circ} \mathrm{C}$. Subcellular fractionation was carried out as described. ${ }^{20}$ Thymi from treated or untreated 4 weeksold animals were disrupted with a Dounce homogenizer (pestle A) for $5 \mathrm{~min}$ in lysis buffer A (300 mM Saccharose, $15 \mathrm{mM} \mathrm{NaCl}, 60 \mathrm{mM} \mathrm{KCl}$, 2 mM EDTA, 15 mM HEPES, 1 mM DTT, 1 mM PMSF, 4 mM NaVO3, $100 \mathrm{mM} \mathrm{NaF}, 30 \mathrm{mM} \mathrm{NaP2O}$, 0.5\% aprotinine). After a $10000 \times g$ centrifugation for $2 \mathrm{~min}$, supernatants were collected as cytoplasmic extracts. Pellets were washed (NP40 $0.3 \%$ in lysis buffer A) and then disrupted into the Dounce homogenizer (pestle B) for $12 \mathrm{~min}$ in lysis buffer B (1.1 M urea, $330 \mathrm{mM} \mathrm{NaCl}, 0.01 \%$ NP40, $27.5 \mathrm{mM}$ HEPES, 
$1 \mathrm{mM}$ DTT, $1 \mathrm{mM}$ PMSF, $4 \mathrm{mM}$ NaVO3, $100 \mathrm{mM} \mathrm{NaF}, 30 \mathrm{mM}$ $\mathrm{NaP2O}, 0.5 \%$ aprotinine) and the lysates were centrifuged for $15 \mathrm{~min}$ at $10000 \times \mathrm{g}$. Supernatants contained nuclear proteins. Protein concentrations were determined using the Bio-Rad protein assay according to Bradford method (595 nm). Extracts were immunoprecipitated for $2 \mathrm{~h}$ with anti-Cbl antibody in excess and then $5 \mathrm{mg}$ of Staphylococcus aureus Protein A Sepharose beads (CL-4B, Pharmacia Biotech Inc.) in $50 \mu \mathrm{l}$ of lysis buffer A were added and incubation was carried out for $45 \mathrm{~min}$. Specificity was tested by preincubating the antibody with blocking peptide P15 in excess $(1 \mathrm{mg} / \mathrm{ml})$ for $3 \mathrm{~h}$ at $4^{\circ} \mathrm{C}$. After a $2500 \times g$ centrifugation for $2 \mathrm{~min}$, pellets were washed three times (PBS-Triton $0.1 \%$; PBS-NaCl $0.5 \mathrm{M}$, PBS only). Immunoprecipitates were boiled with $25 \mu \mathrm{l}$ of sample buffer (Tris- $\mathrm{Hcl}$ $50 \mathrm{mM} \mathrm{pH} 6.5$, bromophenol blue $0.05 \%, \beta$ mercaptoethanol $5 \%$, glycerol $10 \%$ and SDS $2 \%$ ) for $2 \mathrm{~min}$, immediately refreshed on ice and centrifuged. $20 \mu \mathrm{l}$ supernatant were loaded on $10 \%$ SDS - PAGE.

Proteins were transferred to PVDF membranes (TransBlot BioRad) and Western blot analysis was then performed with the $\mathrm{C}-15$ anti-Cb rabbit polyclonal antibody as primary antibody and Aurora Westernblotting detection reagent according to the instructions provided by the supplier (ICN Biomedicals).

\section{Acknowledgements}

Ghislaine Denis and Myriam Verlaet are fellows of the National Fund for Scientific Research (grant Televie). We are grateful to Sophana Ung, C. Hauglustaine and M.C. Petit for their technical assistance. We thank Jean-Luc Baert, Fabrice Soncin, Patrick Dumont, Laetita Rice, Laurent Corsois and Marie-Laure Doucet for helpful discussions.

\section{References}

1. Langdon WY, Hyland CD, Grumont RJ and Morse HC (1989) The c-cbl protooncogene is preferentially expressed in thymus and testis tissue and encodes a nuclear protein. J. Virol. 63: 5420-5424

2. Andoniou CE, Thien CBF and Langdon WY (1994) Tumour induction by activated $\mathrm{Abl}$ involves tyrosine phosphorylation of the product of the $\mathrm{c}-\mathrm{cbl}$ oncogene. EMBO J. 13: 4515-4523

3. Blake TJ, Shapiro M, Morse III HC and Langdon WY (1991) The sequences of the human and the mouse $c-c b /$ proto-oncogene show $\mathrm{v}$ - $c b /$ was generated by a large truncation encompassing a prolin-rich domain and a leucine zipper-like motif. Oncogene 6: 653-657

4. MiyakeS, Lupher MLJr, Andoniou CE, Lill NL, Ota S, Douillard P, RaoN NandBand $\mathrm{H}$ (1997) The Cbl protooncogene product: from an enigmatic oncogene to center stage of signal transduction. Cr. Rev. in Oncog. 8: 189-218

5. Langdon WY, Heath KG and Blake TJ (1992) The localization of the products of the $c$-cbland v-cbloncogenes during mitosis and transformation. Curr. Top. Micr. Immunol. 182: 467-474

6. Meng $\mathrm{F}$ and Lowell CA (1998) A b1 integrin signaling pathway involving Srcfamily kinases, $\mathrm{Cbl}$ and $\mathrm{PI}-3$ kinase is required for macrophage spreading and migration. EMBO J. 17: 4391-4403

7. Andoniou CE, Thien CBF and Langdon WY (1996) The two major sites of Cbl tyrosine phosphorylation in Abl-transformed cells select the crkL SH2 domain. Oncogene 12: 1981-1989

8. de Jong R, Ten Hoeve, J, Heisterkamp N and Groffen J (1995) CrkL is complexed with tyrosine-phosphorylated $\mathrm{Cbl}$ in Ph-positive leukemia. J. Biol. Chem. 270: $21468-21471$

9. Smit $L$ and Borst J (1997) The Cbl family of signal transduction molecules. Cr. Rev. in Oncog. 8: 359-379

10. Deckert M, Elly C, Altman A and Liu YC (1998) Coordinated regulation of the tyrosine phosphorylation of $\mathrm{Cbl}$ by Fyn and Syk tyrosine kinases. J. Biol. Chem. 273: 8867-8874

11. Gesbert F, Garbay C and Bertoglio J (1998) Interleukin-2 stimulation induces tyrosine phosphorylation of $\mathrm{p} 120-\mathrm{Cbl}$ and $\mathrm{CrkL}$ and formation of multimolecular signaling complexes in T lymphocytes and natural killer cells. J. Biol. Chem. 273 3986-3993
12. Lavagna-Sévenier C, Marchetto S, Birnbaum D and Rosnet O (1998) FLT3 signaling in hematopoietic cells involves $\mathrm{Cbl}$, Shc and an unknown p115 as prominent tyrosine-phosphorylated substrates. Leukemia 12: 301-310

13. Park RK, Kyono WT, Liu Y and Durden DL (1998) Cbl-Grb2 interaction in myeloid immunoreceptor tyrosine activation motif signaling. J. Immunol. 160: 50185027

14. Sattler M and Salgia R (1998) Role of the adaptater protein CRKL in signal transduction of normal hematopoietic and BCR/ABL-transformed cells. Leukemia 12: 637-644

15. Ueno H, Sasaki K, Honda H, Nakamoto T, Yamagata T, Miyagawa K, Mitani K, Yazaki Y and Hirai $\mathrm{H}$ (1998) C-Cbl is tyrosine phosphorylated by interleukin-4 and enhances mitogenic and survival signal of interleukin-4 receptor by linking with the phosphatidylinositol 3'-kinase pathway. Blood 91: 46-53

16. Kisielow $P$ and Von Boehmer $H$ (1995) Development and selection of $T$ cells: facts and puzzles. Adv. Immunol. 58: 87-209

17. Surh CD and Sprent J (1994) T-cell apoptosis detected in situ during positive and negative selection in the thymus. Nature 372: $100-103$

18. Thaon S, Quaranta JF and Regnier D (1994) Genetic expression of the C-CBL protooncogene in human thymocytes. Adv. Exp. Med. Biol. 355: 9-13

19. Murphy MA, Schnall RG, Venter DJ, Barnett L, Bertoncello I, Thien CBF, Langdon WY and Bowtell DDL (1998) Tissue hyperplasia and enhanced T-cell signalling via ZAP-70 in c-Cbl-deficient mice. Mol. Cell. Biol. 18: 4872-4882

20. Lupher ML, Songyan Z, Shoeson SE, Cantley LC and Band H (1997) The Cbl phosphotyrosine-binding domain selects a $D(N / D) X p Y$ motif and binds to the TyrP292 negative regulatory phosphorylation site of ZAP-70. J. Biol. Chem. 272: $33140-33144$

21. Cohen JJ (1992) Glucocorticoid-induced apoptosis in the thymus. Semin. Immunol. 4: 363-369

22. Blake TJ, Heath KG and Langdon WY (1993) The truncation that generated the v$\mathrm{cbl}$ oncogene reveals an ability for nuclear transport, DNA binding and acute transformation. EMBO J. 12: 2017-2026

23. Mushinski JF, Goodnight JA, Rudikoff E, Morse HC and Langdon WY (1994) Expression of $c-c b /$ proto-oncogene is modulated during differentiation but not during induction of proliferation. Oncogene 9: 2489-2497

24. Abbadie C (1994) c-Rel: un nouvel oncogèene impliqué dans l'apoptose. Med/ Sc 10: $104-105$

25. Keane MM, Rivero-Lezcano OM, Mitchell JA, Robbins KC and Lipkowitz S (1995) Cloning and characterization of Cbl-b: a SH3-binding protein with homology to the c-cb/ proto-oncogene. Oncogene 10: 2367-2377

26. Zhu J, Shibasaki F, Price R, Guillemot JC, Yano T, Dotsch V, Wagner G, Ferrara $P$ and Mc Keon F (1998) Intramolecular masking of nuclear import signal on NFAT4 by casein kinase and MEKK1. Cell 93: 851-861

27. Baeuerle PA and Baltimore D (1996) NF-kappa B: ten years after. Cell 87: 13-20

28. Huguet C, Mattot V, Bouali F, Stéhelin D, Vandenbunder B and Abbadie C (1997) The avian transcription factor $\mathrm{C}-$ Rel is induced and translocates into the nucleus of thymocytes undergoing apoptosis. Cell Death Differ. 4: 413-422

29. Widmann C, Gibson S and Johnson GL (1998) Caspase-dependent cleavage of signaling proteins during apoptosis. A turn-off mechanism for anti-apoptotic signals. J. Biol. Chem. 273: 7141-7147

30. Miyashita T, Nagao K, Krajewski S, Salvesen GS, Reed JC, Inoue T and Yamada M (1998) Investigation of glucocorticoid-induced apoptotic pathway: Processing of caspase- 6 but not Caspase-3. Cell Death Differ. 5: 1034-1041

31. Kuida K, Zheng TS, NA S, Kuan C, Yang D, Karasuyama H, Rakic P and Flavell RA (1996) Decreased apoptosis in the brain and premature lethality in CPP32deficient mice. Nature 384: 368-372

32. Fukada T, Hibi M, Yamanaka Y, Takahashi-Tezuka M, Fujitani Y, Yamaguchi T, Nakajima K and Hirano T (1996) Two signal are necessary for cell proliferation induced by a cytokine receptor gp 130: involvement of STAT3 in anti-apoptosis. Immunity 5: 449-460

33. Molnar A and Georgopoulos K (1994) The lkaros gene encodes a family of functionnally diverse zinc fingerDNA-binding proteins. Mol. Cell. Biol. 14:82928303

34. Hartley D, Meisner H and Corvera S (1995) Specific association of the beta isoform of the p85 subunit of phosphatidylinositol-3 kinase with the protooncogene c-cbl. J. Biol. Chem. 270: 18260-18263

35. Kitanaka A, Ito C, Nisigaki $H$ and Campana D (1996) CD38-mediated growth suppression of $B$ cell progenitors requires activation of phosphatidylinositol 3kinase and involves its association with the protein product of the $\mathrm{c}-\mathrm{cb} /$ protooncogene. Blood 88: 590-598 
36. Tsygankov AY, Mahajan S, Fincke JE and Bolen JB (1996) Specific association of tyrosine-phosphorylated c-Cbl with Fyn tyrosine kinase in T cells. J. Biol. Chem. 271: 27130-27137

37. SattlerM, Salgia R, Okuda K, Uemura N, Durstin MA, PisickE, Xu G, Li JL, Prasad KV and Griffin JD (1996) The proto-oncogene p120CBL and the adaptator proteins CRKL and c-CRK link c-ABL, p190BCR/ABL and p210BCR/ABL to the phosphatidylinositol-3' kinase pathway. Oncogene 12: 839-846

38. Liu YC, Elly C, Yoshida H, Bonnefoy-Berard N and Altman A (1996) Activationmodulated association of 14-3-3 proteins with $\mathrm{Cbl}$ in T cells. J. Biol. Chem. 271 $14591-14595$

39. Ota $Y$ and Samelson LE (1997) The product of the proto-oncogene c-cbl: a negative regulator of the syk tyrosine kinase. Science 276: 418-420

40. Tanaka S, Amling M, Neff L, Peyman A, Uhlmann E, Levy JB and Baron R (1996) $\mathrm{c}-\mathrm{Cbl}$ is downstream of $\mathrm{c}-\mathrm{Src}$ in a signalling pathway necessary for bone resorption. Nature 383: 528-531

41. Wang Y, Yeung YG, Langdon WY and Stanley RE (1996) c-Cbl is transiently tyrosine-phosphorylated, ubiquitinated and membrane-targeted following CSF1 stimulation of macrophages. J. Biol. Chem. 271: 17-20

42. Yoon CH, Lee J, Jongeward GD and Sternberg PW (1995) Similarity of Sli-1, a regulator of vulval development in $C$. elegans, to the mammalian protooncogene c-cbl. Science 269: 1102-1105

43. Meisner H, Daga A, Buxton J, Fernandez B, Chawla A, Banerjee U and Czech M (1997) Interaction of Drosophila Cbl with epidermal growth factor receptors and role of Cbl in R7 photoreceptor cell development. Mol. Cell. Biol. 17:2217-2225
44. Miyake S, Lupher Jr ML, Druker B and Band H (1998) The tyrosine kinase regulator $\mathrm{Cbl}$ enhances the ubiquitination and degradation of the platelet-derived growth factor receptor alpha. Proc. Natl. Acad. Sci. USA 95: 7927-7932

45. Levkowitz G, Waterman H, Zamir E, Kam Z, Oved S, Langdon WY, Beguinot L, Geiger B and Yarden Y (1998) c-Cbl/Sli-1 regulates endocytic sorting and ubiquitination of the epidermal growth factor receptor. Genes Dev. 12: 36633674

46. Régnier DC, Kozak CA, Kingsley DM, Jenkins NA, Copeland NG, Langdon WY and Morse III HC (1989) Identification of two murine loci homologous to the $v$-cbl oncogene. J. Virol. 63: 3678-3682

47. Bories JC, Willerford DM, Grévin D, Davidson L, Camus A, Martin P, Stéhelin D and Alt FW (1995) Increased T cell apoptosis and terminal B cell differentiation induced by inactivation of the Ets-1 proto-oncogene. Nature 377: 635-638

48. Naramura M, Kole HK, Hu RJ and Gu H (1998) Altered thymic positive selection and intracellular signals in Cbl-deficient mice. Proc. Natl. Acad. Sci. USA 95: $15547-1552$

49. Deman J, Humblet C, Martin MT, Boniver J and Defresne MP (1994) Analysis by in situ hybridization of cells axpressing mRNA for tumor necrosis factor in the developing thymus of mice. Dev. Immunol. 2: 103-109

50. Humblet C, Deman J, Franzen R, Greimers R, Boniver J and Defresne MP (1995) Spontaneous and induced apoptosis after whole body radiation exposure : experimental approaches. Stem Cells 13 suppl: 129-135 